\title{
Peran Orang Tua dalam Meningkatkan Motivasi Belajar Siswa di Masa Pandemi COVID-19
}

\section{Siti Hamida ${ }^{*}$, Elpri Darta Putra ${ }^{2}$}

\author{
1,2 Universitas Islam Riau, Pekanbaru, Indonesia
}

\section{ART ICLE INFO}

Article history:

Received March 09, 2021

Revised April 15, 2021

Accepted August 02, 2021

Available online Auguts 25, 2021

Kata Kunci:

Orangtua, Motivasi Belajar,

Pandemi COVID-19

\section{Keywords:}

Parents, Learning Motivation, COVID-19 Pandemic

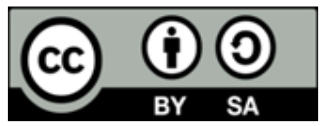

This is an open access article under the CC BY-SA license.

Copyright (@) 2021 by Author. Published by Universitas Pendidikan Ganesha.

\begin{abstract}
A B S T R A K
Pandemi covid-19 memberikan dampak terhadap Pendidikan, yaitu salah satunya rendahnya motivasi belajar siswa. Penelitian ini bertujuan untuk menganalisis peran orang tua dalam meningkatkan motivasi belajar siswa. Jenis penelitian adalah penelitian kualitatif. Penelitian dilakukan di kelas IV Sekolah Dasar, dengan subjek 3 siswa dan 3 orang tua siswa. Metode pengumpulan data menggunakan wawancara, observasi, dan dokumen. Analisis data menggunakan analisis deskriptif kualitatif. Hasil penelitian menunjukkan bahwa peran orang tua dalam motivasi belajar siswa adalah sebagai berikut. Subjek pertama, orang tua memiliki peran yang tinggi dalam motivasi belajar siswa. Subjek memiliki motivasi belajar yang tinggi. Subjek kedua, orang tua memiliki peran memotivasi belajar siswa yang rata-rata. Subjek memiliki motivasi belajar yang rata-rata. Subjek ketiga, peran orang tua dalam memotivasi belajar siswa cukup rendah.Subjek memiliki motivasi belajar yang cukup rendah. Hasil ini menunjukkan bahwa orang tua memiliki peran penting untuk mengembangkan kemampuan anak-anaknya. Orang tua adalah yang pertama dan pendidik utama dalam lingkungan keluarga. Oleh karena itu, diperlukan upaya yang maksimal agar anak terdidik dalam segala aspek dan meningkatkan peran orang tua sebagai pendidik dalam keluarga. Keterlibatan orang tua dalam pendidikan anaknya memotivasi mereka dengan cepat. Implikasi penelitian ini diharapkan dapat memberikan dampak terhadap peran orang tua dalam meningkatkan motivasi belajar siswa.
\end{abstract}

\section{A B S T RACT}

The COVID-19 pandemic has had an impact on education, one of which is the low motivation of students to learn. This study aims to analyze the role of parents in increasing student motivation. This type of research is qualitative research. The research was conducted in the fourth grade of elementary school, with the subject of 3 students and 3 parents of students. Methods of data collection using interviews, observations and documents. Data analysis used descriptive qualitative analysis. The results showed the role of parents in students' learning motivation. The first subject, parents have a high role in student learning motivation, the subject has a high learning motivation. The second subject, parents have an average student motivation, the subject has an average learning motivation and the third subject, the role of parents in student learning motivation is quite low, the subject has a fairly low learning motivation. So, parents have an important role to develop their children's abilities. Parents are the first and have primary educators in the family environment, so maximum efforts are needed so that children are educated in all aspects of developing and increasing the role of parents as educators in the family. The involvement of parents in their children's education motivates them quickly. The implications of this research are expected to have an impact on the role of parents in increasing students' learning motivation.

\section{PENDAHULUAN}

Pendidikan merupakan bagian yang sangat penting dalam proses pembagunan suatu bangsa dan negara karena tanpa didukung pendidikan tidak mungkin pembagunan suatu bangsa dan negara dapat berkembang dengan baik (Alexander et al., 2020; Gerhardt-Szép et al., 2017; Polat \& Aydın, 2020). Dampak covid-19 terhadap dunia pendidikan sangat besar dan dirasakan oleh berbagai pihak, terutama oleh guru, kepala sekolah, peserta didik, dan orang tua (Nasution et al., 2020; Ota et al., 2021; Robandi \& 
Mudjiran, 2020). Akibat penyebaran covid-19 yang tinggi di Indonesia, universitas dan perguruan tinggi lainnya ditutup tidak terkecuali sekolah dasar. Dengan dilakukannya penutupan sekolah, maka pemerintah mengambil langkah agar proses pembelajaran tidak tertinggal dan peserta didik tetap menerima hak untuk mendapatkan ilmu (Hatmo, 2021; Siahaan, 2020). Maka dari itu, keputusan pemerintah selanjutnya yaitu proses pembelajaran tetap berlangsung tapi tidak dengan tatap muka melainkan dengan online. Kebijakan ini tentunya tidak hanya berdampak pada guru dan murid selama BDR, namun juga pentingnya optimalisasi peran orang tua dalam pelaksanaan BDR (D. R. Dewi et al., 2021; Kurniati et al., 2020). Peran orang tua dalam mendampingi kesuksesan anak selama belajar di rumah menjadi sangat sentral. Terkait dengan hal tersebut, WHO merilis berbagai panduan bagi orang tua ketika mendampingi putra-putri belajar selama pandemi ini berlangsung yang meliputi tips pengasuhan agar lebih positif dan konstuktif saat mendampingi anak selama beraktivitas di rumah (Efendi \& Didik, 2020; Kurniati et al., 2020). Orang tua pada awalnya berperan dalam membimbing sikap serta keterampilan yang mendasar, seperti pendidikan agama mengajarkan agar anak patuh terhadap aturan dan untuk pembiasaan yang baik, namun perannya menjadi meluas yaitu sebagai pendamping pendidikan akademik (P. A. S. C. Dewi \& Khotimah, 2020; Pohan, 2020).

Kenyataannya menunjukkan bahwa dunia pendidikan saat ini mengalami permasalahan yang sangat rumit. Permasalahan menjadi kendala yang menghambat kelancaran proses belajar mengajar di sekolah. Bentuk permasalahan kerap muncul dalam berbagai variasi. Di antaranya, kurangnya motivasi anak dalam belajar. minat belajar yang rendah, dan sebagainya (Hutauruk \& Sidabutar, 2020; Muhammad Fikri, Muhammad Zaki Ananda, 2021). Adanya permasalahan tersebut menunjukkan bahwa proses belajar mengajar kurang memberi makna bagi siswa. Sikap itu juga menunjukkan bentuk ketidaksenangan siswa terhadap belajar. Banyak siswa yang tampak tidak memiliki keinginan belajar (Cahyaningtyas, 2020; Fitriyani \& Sari, 2020). Siswa terpaksa menjalani pendidikan di sekolah padahal prinsipnya kekurangan motivasi untuk belajar (Garbe et al., 2020; Guay et al., 2010). Dalam permasalahan ini orang tua harus bertanggung jawab untuk mengarahkan dan mendampingi siswa dalam aktivitas belajarnya, sehingga dapat mengetahui tahapan-tahapan pembelajarannya. Berdasarkan prasurvei di SD Negeri 008 Labuhan Papan Kabupaten Rokan Hilir diketahui bahwa orang tua sudah cukup berperan dalam meningkatkan motivasi anak. Bentuk motivasi yang diberikan oleh orang tua hanya pada pembiayaan dan kata-kata nasihat, tetapi keseharian anak masih kurang mendapakan perhatian karena orang tua sibuk bekerja. Fasilitas yang diberikan orang tua kepada anak kurang memadai. Selain anak yang kurang mendapatkan perhatian dari orang tua yang bersikap acuh terhadap waktu belajar, anak sering menonton televisi saat jam belajar, bermain gadget, dan bermain dengan teman-temannya. Interaksi antara orang tua dan anak sangat berpengaruh dalam meningkatkan motivasi belajar anak. Banyak orang tua yang memperbolehkan anaknya bermain. Hal ini mengakibatkan anak memiliki rasa kebergantungan dan berpengaruh dalam motivasi minat belajarnya.

Orang tua adalah pendidik pertama bagi anak-anaknya karena dari orang tuanya anak-anak mulai menerima pendidikan (Sakti, 2021; Santosa et al., 2018). Bentuk pendidikan anak terdapat dalam kehidupan keluarga. Keluarga merupakan pusat kasih sayang yang saling membantu antara sesama. Orang tua berkewajiban dan bertanggung jawab mendidiknya di rumah dengan baik terhadap keberlangsungan pendidikan anaknya di masa depan (Nouwen \& Zaman, 2018; Yulianingsih et al., 2020). Pendidikan yang diterima dalam keluarga inilah yang akan digunakan oleh anak sebagai dasar untuk mengikuti pendidikan selanjutnya di sekolah. Jika orang tua menanamkan perbuatan disiplin, maka anak akan menerapkan di lingkungan sekolah maupun di lingkungan masyarakat (Atmojo \& Nugroho, 2020; Ramdan \& Fauziah, 2019). Penerapan nilai sikap hidup yang diberikan kepada anak-anak mereka dapat memunculkan pengembangan bakat, minat, kepribadian, serta motivasi anak. Pengasuhan orang tua terhadap anaknya dapat berpengaruh terhadap pembentukan karakter dan perilaku anak itu sendiri (Nur, 2016; Syahrul \& Nurhafizah, 2021). Apabila terdapat kesalahan pengasuhan, maka akan berdampak pada anak saat sudah dewasa. Motivasi diartikan sebagai kekuatan, dorongan, kebutuhan, semangat, tekanan, atau mekanisme psikologis yang mendorong seseorang atau sekelompok orang untuk mencapai prestasi tertentu sesuai dengan yang dikehendakinya. Para orang tua menyadari pentingnya motivasi anak sebagai bentuk dukungan orang tua terhadap proses perkembangan belajar anak (Wijayanti \& Fauziah, 2020; Yulianingsih et al., 2020). Semua orang tua berupaya memberikan motivasi kepada anak supaya mereka merasa diperhatikan dan dapat dukungan dari orang tua dalam proses belajar. Dengan demikian, anak lebih bersemangat belajar dan dapat hasil belajar yang lebih baik ('Aisyatinnaba \& Sutoyo, 2016; Wardana, 2016).

Temuan penelitian sebelumnya menyatakan orang tua memiliki peran tinggi dalam memotivasi belajar siswa diikuti dengan motivasi belajar siswa yang tinggi ('Aisyatinnaba \& Sutoyo, 2016). Pola asuh yang diterapkan kepada anak dan mampu membuat motivasi belajar anak, sehingga mendapatkan hasil belajar yang maksimal (Syahrul \& Nurhafizah, 2021). Pola asuh demokratis juga dapat membentuk 
karakter berupa kedisiplinan, kemandirian, religius, dan komunikatif (Nadhifah et al., 2021). Orang tua memiliki pengaruh penting dalam mendampingi anak selama proses pembelajaran daring (Atmojo \& Nugroho, 2020; Garbe et al., 2020). Penelitian ini bertujuan untuk menganalisis peran orang tua dalam memotivasi minat belajar siswa kelas IV SD Negeri 008 Labuhan Papan Kabupaten Rokan Hilir.

\section{METODE}

Penelitian ini merupakan penelitian kualitatif. Penelitian kualitatif dapat diartikan bahwa penelitian ini tidak menggunakan statistik sebagai analisis data. Oleh karena itu, data-data yang dikumpulkan tidak berupa angka melainkan kata-kata dan tindakan dan segala fenomena yang terdapat di lapangan yang berhubungan dengan peran orang tua dalam memotivasi siswa. Data tersebut digali dalam penelitian ini melalui upaya observasi, wawancara dengan tiga orang tua siswa, tiga siswa, guru kelas, dan kepala sekolah di SDN 008 Labuhan Papan, serta melalui upaya dokumentasi. Keabsahan data dalam penelitian ini adalah keabsahan data terdiri dari beberapa kriteria yang sudah ditentukan antara lain kepercayaan, keteralihan, kebergantungan dan kepastian. Hasil penelitian ini dapat dipertanggung jawabkan dengan adanya keabsahan hasil penelitian yang disebut dengan keabsahan data.

Uji keabsahan data penelitian ini menggunakan uji kreadibilitas yaitu uji kreadibilitas data atau kepercayaan terhadap hasil penelitian menggunakan teknik trianggulasi. Menurut Syahrial (2019) triangulasi merupakan teknik pemeriksaan keabsahan data yang menggunakan sumber di luar data tersebut atau membandingkan triangulasi dengan sumber data. Dalam penelitian ini digunakan teknik triangulasi sumber yang dicapai melalui cara membandingkan data hasil pengamatan dan data hasil wawancara. Sedangkan triangulasi teknik yaitu mengecek data kepada sumber yang sama dengan teknik berbeda. Untuk menganalisis data menggunakan data menurut Miles dan Huberman, aktivitas dalam analisis data kualitatif dilakukan secara interaktif dan berlangsung secara terus menerus sampai tuntas, sehingga datanya sudah jenuh.

\section{HASIL DAN PEMBAHASAN}

Hasil penelitian yang bertujuan menganalisis peran orang tua dalam peningkatan motivasi belajar siswa kelas IV SD Negeri 008 Labuhan Papan Kabupaten Rokan Hilir memperoleh data yang berkaiatan dengan peran orang tua dalam memotivasi siswa. Beberapa hasil penelitian yang berkaitan dengan peran orang tua. Pertama, orang tua sebagai motivator. Orang tua merupakan sumber motivasi bagi anak. Dengan adanya motivasi yang telah diberikan oleh orang tua, maka akan meningkatkan motivasi belajarnya. Sebagai motivator, orang tua memberikan motivasi kepada anak dengan cara memberi penghargaan terhadap prestasi belajar anak, memberikan hadiah, kata-kata pujian, atau hukuman. (Garbe et al., 2020; Nugraheni, 2019). Orang tua dapat juga, memberikan bantuan kepada anak dalam menghadapi kesulitan belajarnya dengan pemberian penjelasan pada bagian yang sulit dipahami oleh anak. Sesuai dengan teori pemberian motivasi kepada anak sudah dilakukan oleh orang tua pertama yang selalu memberikan motivasi kepada anak agar anak bisa menyelesaikan tugasnya. Jika tugasnya belum selesai, maka anak tersebut tidak diizinkan untuk bermain-main, sehingga anak menjadi termotivasi untuk mengerjakan tugasnya sampai selesai. Orang tua kedua hanya memberikan motivasi ketika anak ada tugas. Orang tua ketiga memberikan motivasi kepada anak agar anak bisa mengerjakan tugasnya dengan baik sampai selesai. Pemberian motivasi yang berasal dari orang tua merupakan motivasi ekstrinsik yang berasal dari luar diri individu. Motivasi ekstrinsik adalah pendorong kerja yang bersumber dari luar diri individu. Salah satu motivasi eksternal adalah lingkungan dan orang tua (Hafida, 2020; Nur, 2016).

Motivasi yang bisa diberikan orang tua kepada anak dengan cara memberikan semangat belajar. Sesuai dengan teori pemberian motivasi kepada anak sudah dilakukan oleh orang tua pertama yang memberikan semangat ketika anak hendak pergi ke sekolah untuk belajar. Orang tua mengucapkan "anak ibu semangat ya belajarnya di sekolah". Orang tua kedua memberikan semangat dengan cara memerhatikan anak setiap hari saat hendak pergi ke sekolah dan apabila pulang sekolah orang tua kedua selalu menanyakan kegiatan anak dan menanyakan ada atau tidak pekerjaan rumahnya (PR. Menurut orang tua kedua, dengan memerhatikan anak seperti itu akan membuatnya semangat dalam belajar. Orang tua ketiga memberikan semangat ketika anak merasa kesulitan dalam belajar, memberikan bantuan saat anak mengerjakan PR. Pemberian motivasi yang bisa dilakukan orang tua dengan pemberian hadiah atau pujian kepada anak. Pada orang tua pertama mengatakan bahwa ketika sang anak mendapat nilai bagus atau mendapat juara dalam perlombaan, orang tua tersebut selalu memberikan pujian seperti mengatakan "waah anak pintar, hebat yaa mantap besok tingkatkan lagi" dan terkadang memberikan 
hadiah berupa peralatan sekolah yang baru seperti buku gambar atau barang lainnya. Orang tua kedua dalam memotivasi belajar anak dengan memberikan pujian dengan mengucapkan "anak yang ganteng, anak pandai" sambil memberi acungan jempol. Orang tua ini jarang memberikan hadiah ketika anak mendapatkan nilai bagus. Berbeda halnya dengan orang tua ketiga. Orang tua ini mengatakan bahwa ketika anaknya mendapatkan juara kelas atau melakukan hal yang baik, maka beliau dengan spontan memberikan pujian seperti "waaah hebat anak bapak, good good good sambil memberi acungan 2 jempol" dan terkadang memberikan hadiah yang diinginkan sang anak. Pemberian reward pada umumnya adalah pemberian penghargaan kepada seseorang atas sesuatu yang telah dihasilkan (Cheung \& Joyce Lok YinKwan, 2021; Garbe et al., 2020; Sujiantari, 2016).

Pemberian motivasi yang bisa dilakukan oleh orang tua selanjutnya pemberian bantuan kepada anak, orang tua siswa pertama, kedua, dan ketiga sama-sama memberikan bantuan kepada anak jika anak merasa kesulitan saat mengerjakan tugas sekolahnya. Pada orang tua pertama mengatakan jika sang anak mengalami kesulitan dalam mengerjakan tugas atau PR, maka orang tua meminta anak untuk berusaha mencari jawabannya terlebih dahulu. Jika jawabannya tidak ada di buku, maka orang tua memberikan rambu-rambu jawaban dengan memancing atau menimbulkan pertanyaan dengan menanyakan manakah jawaban yang benar menurut anak. Sedangkan pada orang tua kedua membantu dengan cara memberikan jawaban atas tugas yang tidak diketahui anak. Orang tua ketiga mengatakan bahwa jika anak mengalami kesulitan dalam belajar, orang tua siap membantu. Kedua, orang tua sebagai fasilitator. Peran orang tua sebagai fasilitator sudah dapat dikatakan cukup baik karena orang tua sudah memberikan fasilitas yang terbaik untuk anaknya. Fasilitas yang diberikan oleh orang tua kepada anak seperti ruangan \& meja belajar, buku pelajaran, serta alat tulis. Peran orang tua dalam meningkatkan motivasi anak, salah satunya dengan menyediakan fasilitas belajar. Dalam penyelenggaraan belajar di rumah, yang bertanggung jawab untuk menyediakan fasilitas belajar anak adalah orang tua. Hal ini sangat menunjang kegiatan belajar anak. Dengan adanya fasilitas yang lengkap, maka akan sangat menunjang dan meningkatkan minat belajar anak (Efendi \& Didik, 2020; Yulianingsih et al., 2020).

Ketiga, orang tua sebagai pembimbing. Pemberian bimbingan yang diberikan oleh ketiga orang tua siswa sama-sama memberi bimbingan ketika anak mengalami kesulitan belajar. Orang tua juga memberikan bimbingan dengan mengarahkan anak jika anak tidak tahu jawaban dari pertanyaan yang ada pada soal. Peran orang tua menyediakan fasilitas belajar atau sarana belajar serta membantu kesulitan belajar (Green et al., 2020; Rusmiati et al., 2020). Kesulitan belajar yang dialami anak bisa dibantu dan dibimbing oleh orang tua siswa. Bimbingan adalah segala kegiatan yang dilakukan oleh seseorang dalam rangka memberikan bantuan kepada orang lain yang mengalami kesulitan agar orang tersebut mampu mengatasinya sendiri dengan penuh kesadaran (Hasgimianti et al., 2017; Saya, 2020). Kendala yang dihadapi orang tua dalam memotivasi belajar anak kelas IV SD Negeri 008 Labuhan Papan Kabupaten Rokan Hilir terletak pada faktor ekonomi yang kurang mendukung, sehingga beberapa orang tua kurang mampu memberikan fasilitas belajar anak. Kendala lainnya adalah kurangnya kerjasama antara guru dan orangtua. Beberapa orang tua berpendapat bahwa apabila anak berada di sekolah, maka ini menjadi tanggug jawab pihak sekolah dalam membimbing anak belajar. Halini menunjukkan bahwa beberapa orang tua masih kurang memberikan andil dan keikutsertaanya dalam meningkatkan kualitas pendidikan.

Temuan ini diperkuat dengan penelitian sebelumnya yang menyatakan bahwa orang tua memiliki peran tinggi dalam memotivasi belajar siswa diikuti dengan motivasi belajar siswa yang tinggi ('Aisyatinnaba \& Sutoyo, 2016). Pola asuh yang diterapkan kepada anak dan mampu membuat motivasi belajar anak, sehingga mendapatkan hasil belajar yang maksimal (Syahrul \& Nurhafizah, 2021). Pola asuh demokratis juga dapat membentuk karakter berupa kedisiplinan, kemandirian, religius, dan komunikatif (Nadhifah et al., 2021). Orang tua memiliki pengaruh penting dalam mendampingi anak selama proses pembelajaran daring (Atmojo \& Nugroho, 2020; Garbe et al., 2020). Pola asuh orang tua berhubungan secara signifikan terhadap hasil belajar (Wulandari \& Renda, 2020). Pola asuh orang tua yang baik akan menimbulkan motivasi belajar siswa yang baik pula (Rizqi \& Sumantri, 2019). Semakin baik motivasi belajar siswa semakin tinggi pula hasil belajar siswa (Ambarwati, Awalul Badriyatal, 2013; Permana, 2016). Jadi, peran orang tua sangatlah penting dalam mendukung proses pembelajaran. Peran orang tua dalam memotivasi siswa yang baik akan meningkatkan minat belajar siswa yang baik juga yang tentunya akan memengaruhi hasil belajar dan prestasi sekolah. Berdasarkan hasil penelitian ini diketahui masih sangat dibutuhkan sebuah dukungan berbagai pihak untuk meningkatkan motivasi belajar siswa dalam mengikuti pembelajaran daring. 


\section{SIMPULAN}

Peran orang tua sangat besar terhadap keberhasilan anak, maka dibutuhkan peran orang tua sebagai fasilitator yang memfasilitasi semua kebutuhan belajar anak. Tidak hanya sebagai fasilitator dan motivator, peran orang tua juga sebagai pembimbing bagi anak. Orang tua membimbing, membantu, memantau, serta mengarahkan anak dalam belajar. Akibat pemberian motivasi orang tua seperti memfasilitasi semua kebutuhan belajar anak, selalu menjadi motivator bagi anak, memberikan semangat untuk anak, memberikan anak pujian dan hadiah jika anak melakukan hal baik, membimbing, membantu, memantau serta mengarahkan anak dalam proses pembelajaran akan menumbuhkan minat belajar anak. Peran orang tua sangat dibutuhkan oleh anak untuk mendorong anak lebih semangat dalam proses belajar. Karena dengan adanya dorongan itu, anak akan termotivasi dan jiwa anak akan tersentuh karena kasih sayang orang tua kepada anak selalu ada. Hambatan yang dialami oleh orang tua dalam memotivasi belajar anak antara lain faktor ekonomi yang kurang mendukung, sehingga orangtua kurang mampu memberikan fasilitas belajar anak. Terkait dengan kurangnya kerja sama antara guru dan orang tua, beberapa orang tua berpendapat bahwa apabila anak berada di sekolah, ini menjadi tanggug jawab pihak sekolah dalam membimbing anak belajar, sehingga beberapa orangtua masih kurang memberikan andil dan keikutsertaanya dalam meningkatkan kualitas pendidikan.

\section{DAFTAR PUSTAKA}

Aisyatinnaba, N., \& Sutoyo, A. (2016). Peran Orang Tua dalam Memotivasi Belajar Siswa. Indonesian Journal of Guidance and Counseling: Theory and Application, 5(4), 54-57. https://doi.org/10.15294/IJGC.V5I4.13520.

Alexander, C., Wyatt-Smith, C., \& Du Plessis, A. (2020). The Role of Motivations and Perceptions on the Retention of Inservice Teachers. Teaching and Teacher Education, 96, 103186. https://doi.org/10.1016/j.tate.2020.103186.

Ambarwati, Awalul Badriyatal, I. A. I. N. P. 2020. (2013). Pengaruh Bimbingan Orang Tua dan Motivasi Belajar dalam Pembelajaran Baca Tulis Qur'an (Btq) terhadap Kemampuan Membaca Al-Qur'an Anak di Madrasah Diniyah Thoriqul Ihsan Bulu Kidul Balong Ponorogo. Journal of Chemical Information and Modeling, 53(9), 1689-1699.

Atmojo, A. E. P., \& Nugroho, A. (2020). EFL Classes must go Online! Teaching Activities and Challenges During COVID-19 Pandemic in Indonesia. Register Journal, 13(1), 49-76. https://doi.org/10.18326/rgt.v13i1.49-76.

Cahyaningtyas, T. N. (2020). Analisis Dampak Pandemi Virus Corona terhadap Motivasi Belajar Siswa Kelas II SD Percobaan II Malang. Seminar Nasional PGSD UNIKAMA, 4, 1-7. https://conference.unikama.ac.id/artikel/.

Cheung, S. K., \& Joyce Lok YinKwan. (2021). Parents' Perceived Goals for Early Mathematics Learning and Their Relations with Children's Motivation to Learn Mathematics. Early Childhood Research Quarterly, 56(3), 90-102. https://doi.org/10.1016/j.ecresq.2021.03.003.

Dewi, D. R., Drupadi, R., \& Syafrudin, U. (2021). Pengaruh Pembelajaran Daring terhadap Aspek Perkembangan Sosial Anak Usia 5-6 Tahun. 5(02), 55-62. https://doi.org/10.29408/jga.v5i01.3066.

Dewi, P. A. S. C., \& Khotimah, H. (2020). Pola Asuh Orang Tua pada Anak di Masa Pandemi Covid-19. Seminar Nasional Sistem Informasi, 2433-2441.

Efendi, \& Didik. (2020). Peran Orang Tua dalam Pembelajaran Model Distance Learning di Sekolah Dasar Kota Jayapura. Al-Madrasah: Jurnal Pendidikan Madrasah Ibtidaiyah, 5(1), 54-66. https://doi.org/10.35931/am.v5i1.400.

Fitriyani, \& Sari. (2020). Motivasi Belajar Mahasiswa pada Pembelajaran Daring selama Pandemik Covid19. Jurnal Kependidikan: Jurnal Hasil Penelitian Dan Kajian Kepustakaan Di Bidang Pendidikan, Pengajaran, Dan Pembelajaran, 6(2), 165-175. https://doi.org/https://doi.org/10.33394/jk.v6i2.2654.

Garbe, A., Ogurlu, U., Logan, N., \& Cook, P. (2020). Parents' Experiences with Remote Education during COVID-19 School Closures. American Journal of Qualitative Research, 4(3), 45-65. https://doi.org/10.29333/ajqr/8471.

Gerhardt-Szép, S., Dreher, S., Rüttermann, S., \& Weberschock, T. (2017). Konzeption und Implementierung eines neuartigen E-Learning-Moduls mit EbM-Lerninhalten im Fach Zahnerhaltungskunde. Zeitschrift Fur Evidenz, Fortbildung Und Qualitat Im Gesundheitswesen, 127-128, 72-78. https://doi.org/10.1016/j.zefq.2017.09.001.

Green, J. K., Burrow, M. S., \& Carvalho, L. (2020). Designing for Transition: Supporting Teachers and Students Cope with Emergency Remote Education. Postdigital Science and Education, 2(3), 906- 
922. https://doi.org/10.1007/s42438-020-00185-6.

Guay, F., Chanal, J., Ratelle, C. F., Marsh, H., Larose, S., \& Boivin, M. (2010). Intrinsic, identified, and Controlled Types of Motivation for School Subjects in Young Elementary School Children. British Journal of Educational Psychology, 80(4), 711-735. https://doi.org/10.1348/000709910X499084.

Hafida, dkk. (2020). Penurunan Motivasi dan Keaktifan Belajar Siswa selama Pembelajaran Daring di Tengah Pendemi Covid-19. Indonesian Journal Of Education Scince, 2(2), 82.

Hasgimianti, Nirwana, H., \& Daharnis. (2017). Perhatian Orang Tua dan Motivasi Belajar Siswa yang Berlatar Belakang Melayu dan Jawa. Insight: Jurnal Bimbingan Dan Konseling, 6(2), 130 - 143. https: //doi.org/10.21009/INSIGHT.062.02.

Hatmo, S. H. D. (2021). Dampak Pandemi Covid-19 terhadap Efektivitas Pembelajaran Jarak Jauh Secara Daring. Scholaria: Jurnal Pendidikan Dan Kebudayaan, 11(2), 115-122. https: //ejournal.uksw.edu/scholaria/article/view/4222.

Hutauruk, A., \& Sidabutar, R. (2020). Kendala Pembelajaran Daring selama Masa Pandemi di Kalangan Mahasiswa Pendidikan Matematika: Kajian Kualiatatif Deskriptif. SEPREN: Journal of Mathematics Education and Applied, 02(01), 45-51. https://doi.org/10.36655/sepren.v2i1.364.

Kurniati, E., Nur Alfaeni, D. K., \& Andriani, F. (2020). Analisis Peran Orang Tua dalam Mendampingi Anak di Masa Pandemi Covid-19. Jurnal Obsesi: Jurnal Pendidikan Anak Usia Dini, 5(1), 241. https://doi.org/10.31004/obsesi.v5i1.541.

Muhammad Fikri, Muhammad Zaki Ananda, N. F. (2021). Kendala dalam Pembelajaran Jarak Jauh di Masa Pandemi Covid-19: Sebuah Kajian Kritis. Jurnal Education and Development Institut Pendidikan Tapanuli Selatan, 9(1), 145-148. https://doi.org/10.37081/ed.v9i1.2290.

Nadhifah, I., Kanzunnudin, M., \& Khamdun. (2021). Analisis Peran Pola Asuh Orangtua terhadap Motivasi Belajar Anak. Jurnal Education FKIP UNMA, 7(1), $91 \quad$ - 96. https: //doi.org/10.31949/educatio.v7i1.852.

Nasution, D. A. D., Erlina, E., \& Muda, I. (2020). Dampak Pandemi COVID-19 terhadap Perekonomian Indonesia. Jurnal Benefita, 5(2), 212. https://doi.org/10.22216/jbe.v5i2.5313.

Nouwen, M., \& Zaman, B. (2018). Redefining the Role of Parents in Young Children's Online Interactions. A Value-Sensitive Design Case Study. International Journal of ChildComputer Interaction, 18, 22-26.

Nugraheni, S. (2019). Hubungan Antara Motivasi Belajar dengan Disiplin Belajar Siswa. Journal for Lesson and Learning Studies, 2(1), 30-36. https: //doi.org/10.23887/jlls.v2i1.17317.

Nur, A. S. (2016). Pengaruh Pola Asuh Orang Tua, Konsep Diri, dan Motivasi Berprestasi terhadap Prestasi Belajar Matematika Siswa Kelas IX SMP Negeri di kota Merauke. Suska Journal of Mathematics Education, 2(2), 89 - 96. https://doi.org/10.24014/sjme.v2i2.2067.

Ota, M. K., Djou, A. M. G., \& Numbah, F. F. (2021). Problematika Pembelajaran Daring Siswa Kelas Vii SMPN. Jurnal Pengabdian Masyarakat, 2(1), 74-81. https://doi.org/10.37478/mahajana.v2i1.769.

Permana, A. (2016). Pengaruh Gaya Belajar dan Motivasi Belajar Mahasiswa terhadap Kemampuan Belajar Ilmu Alamiah Dasar. Formatif: Jurnal Ilmiah Pendidikan MIPA. https://doi.org/10.30998/formatif.v6i3.999.

Pohan, S. S. (2020). Paradigma Pengajaran Jarak Jauh (PJJ) bagi Guru Sekolah Dasar. Satya Widya, 3, $25-34$.

Polat, Ö., \& Aydın, E. (2020). The Effect of Mind Mapping on Young Children's Critical Thinking Skills. Thinking Skills and Creativity, 38. https://doi.org/10.1016/j.tsc.2020.100743.

Ramdan, A. Y., \& Fauziah, P. Y. (2019). Peran Orang Tua dan Guru dalam Mengembangkan Nilai-nilai Karakter Anak Usia Sekolah Dasar. Jurnal Pendidikan Dasar Dan Pembelajaran, 9(2), 100. https://doi.org/10.25273/pe.v9i2.4501.

Rizqi, A. T., \& Sumantri, M. (2019). Hubungan antara Motivasi Belajar dan Pola Asuh Orang Tua terhadap Hasil Belajar IPA. Jurnal Imiah Pendidikan Dan Pembelajaran, 3(2), 145-154. https: //doi.org/10.23887/jipp.v3i2.18071.

Robandi, D., \& Mudjiran, M. (2020). Dampak Pembelajaran dari Masa Pandemi Covid-19 terhadap Motivasi Belajar Siswa SMP di Kota Bukittinggi. Jurnal Pendidikan Tambusai, 4(3), 3498-3502. https://doi.org/10.31004/jptam.v4i3.878.

Rusmiati, A. R., Reza, R., Achmad, S., Syaodih, E., Nurtanto, M., Sultan, A., Riana, A., \& Tambunan, S. (2020). PThe Perceptions of Primary School Teachers of Online Learning during the COVID-19 pandemic Period : A Case Study in Indonesia. Journal of Ethnic and Cultural Studies, 7(2), 90-109.

Sakti, S. A. (2021). Persepsi Orang Tua Siswa terhadap Pembelajaran Daring pada Masa Pandemi Covid 19 di Yogyakarta. Jurnal Obsesi, 6(1). https://doi.org/10.31004/obsesi.v6i1.804.

Santosa, A. I., Rafli, Z., \& Lustyantie, N. (2018). Pengaruh Pola Asuh Orang Tua dan Sikap Bahasa terhadap Kemampuan Membaca Pemahaman. Jurnal Pendidikan Bahasa Dan Sastra, 6(2), 69-80. https://doi.org/10.30659/j.6.2.91-103.

Saya, S. (2020). Pengaruh Pola Asuh Orang Tua dan Disiplin Belajar terhadap Prestasi Belajar Siswa. Jurnal 
Pendidikan Dan Bimbingan Konseling, 1(1), 1-6.

Siahaan, M. (2020). Dampak Pandemi Covid-19 terhadap Dunia Pendidikan. Jurnal Kajian Ilmiah (JKI), 20(1), 1-3.

Sujiantari, N. K. (2016). Pengaruh Reward dan Punishment terhadap Motivasi Belajar Siswa dalam Pembelajaran IPS (Studi pada SMP Negeri 1 Singaraja kelas VIII Tahun Ajaran 2015/2016). Jurnal Jurusan Pendidikan Ekonomi (JJPE), 7(2), 1-10. https://doi.org/10.23887/jjpe.v7i2.7573.

Syahrul, \& Nurhafizah. (2021). Analisis Pengaruh Pola Asuh Orang Tua terhadap Perkembangan Sosial dan Emosional Anak Usia Dini di masa Pandemi Corona Virus 19. Jurnal Basicedu, 5(2), 683-696. https://doi.org/10.31004/basicedu.v5i2.792.

Wardana, M. D. K. (2016). Implementasi Surat Edaran Mendikbud terhadap Peran Orang Tua pada Hari Pertama Sekolah. Pedagogia: Jurnal Pendidikan, 5(2), $169-178$. https://doi.org/10.21070/pedagogia.v5i2.248.

Wijayanti, R. M., \& Fauziah, P. Y. (2020). Perspektif dan Peran Orang tua dalam Program PJJ Masa Pandemi Covid-19 di PAUD. Jurnal Obsesi: Jurnal Pendidikan Anak Usia Dini, 5(2), 1304-1312. https://doi.org/10.31004/obsesi.v5i2.768.

Wulandari, A. P., \& Renda, N. T. (2020). Hubungan antara Pola Asuh Orang Tua dan Motivasi Belajar Matematika Siswa. Mimbar Ilmu, 25(2), 90. https://doi.org/10.23887/mi.v25i2.26068.

Yulianingsih, W., Suhanadji, S., Nugroho, R., \& Mustakim, M. (2020). Keterlibatan Orangt ua dalam Pendampingan Belajar Anak selama Masa Pandemi Covid-19. Jurnal Obsesi : Jurnal Pendidikan Anak Usia Dini, 5(2), 1138-1150. https://doi.org/10.31004/obsesi.v5i2.740. 